\title{
Factors controlling erosion/deposition phenomena related to lahars at Volcán de Colima, Mexico
}

\author{
Rosario Vázquez, Lucia Capra, and Velio Coviello \\ Centro de Geociencias, UNAM-Campus Juriquilla, Querétaro, C.P., 76046, Mexico \\ Correspondence to: Rosario Vázquez (rvazmor@geociencias.unam.mx)
}

Received: 20 April 2016 - Published in Nat. Hazards Earth Syst. Sci. Discuss.: 12 May 2016

Revised: 11 July 2016 - Accepted: 24 July 2016 - Published: 15 August 2016

\begin{abstract}
One of the most common phenomena at Volcán de Colima is the annual development of lahars that runs mainly through the southern ravines of the edifice. Since 2011 the study and the monitoring of these flows and of the associated rainfall has been achieved by means of an instrumented station located along the Montegrande ravine, together with the systematic surveying of cross-topographic profiles of the main channel. From these, we present the comparison of the morphological changes experimented by this ravine during the 2013, 2014 and 2015 rainy seasons. The erosion/deposition effects of 11 lahars that occurred during this period of time were quantified by means of the topographic profiles taken at the beginning and at the end of the rainy seasons and before and after the major lahar event of 11 June 2013. We identified (i) an erosive zone between 2100 and $1950 \mathrm{~m}$ a.s.l., $8^{\circ}$ in slope, with an annual erosional rate of $10.3 \%$ mainly due to the narrowness of the channel and to its high slope angle and (ii) an erosive-depositional zone, between 1900 and $1700 \mathrm{~m}$ a.s.l., $(\sim 8 \%$ erosion and $\sim 16 \%$ deposition), characterized by a wider channel that decreases in slope angle $\left(4^{\circ}\right)$. Based on these observations, the major factors controlling the erosion/deposition rates in the Montegrande ravine are the morphology of the gully (i.e., channel bed slope and the cross section width) and the joint effect of sediment availability and accumulated rainfall. On the distal reach of the ravine, the erosion/deposition processes tend to be promoted preferentially one over the other, mostly depending on the width of the active channel. Only for extraordinary rainfall events are the largest lahars mostly erosive all along the ravine up to the distal fan where the deposition takes place. In addition, as well as the morphological characteristics of the ravine, the flow depth is a critical factor in controlling erosion, as deeper flows will promote ero-
\end{abstract}

sion against deposition. Finally, by comparing rainfalls associated with lahars that originated after the last main eruptive episode that occurred in 2004-2005, we observed that higher accumulated rainfall was needed to trigger lahars in the 2013 and 2014 seasons, which points to a progressive stabilization of the volcano slope during a post-eruptive period. These results can be used as a tool to foresee the channel response to future volcanic activity, to improve the input parameters for lahar modeling and to better constrain the hazard zonation at Volcán de Colima.

\section{Introduction}

Lahars are concentrated mixtures of debris, sediment, and water that move rapidly down volcanic slopes under gravity (Smith and Fritz, 1989). According to their water-sediment rate, they can be defined as hyperconcentrated flows, between 20 and $60 \%$ in volume (Beverage and Culbertson, 1964), and extremely coarse sediment-rich debris flows, with sediment concentration $>60 \%$ in volume (Costa, 1984, 1987; Pierson and Costa, 1987). However, as described by Pierson (2005), flow behavior will be strongly controlled by grain-size distribution, sediment-transport mechanisms, and their hydrodynamic characteristics. Flow volume and discharge can increase by several times downstream due to the entrainment of sediment and water (Vallance, 2000; Scott et al., 2005). Nonetheless, whether it is a hyperconcentrated or a debris flow, or the evolution of both during the same event, the formation of lahars depends upon the availability of easily erodible sediments from the channel bed or lateral terraces, to bulk up the flow (Scott, 1988; Pierson, 1995; Scott et al., 2005). Furthermore, additional volume changes can oc- 
cur by dilution due to tributary streamflows, overrunning active stream channels or entrainment of water-saturated sediments (Pierson and Scott, 1985; Costa, 1987; Cronin et al., 1999). All of these flow changes control the capacity of lahars to modify the morphology of the channels where they flow, as observed in several studies (Muñoz-Salinas et al., 2008, 2009; Doyle et al., 2009, 2011; Starheim et al., 2013; Andrés de Pablo et al., 2014), not only in volcanic environments, but also in mountainous regions in the form of debris flows. The role that the slope, the sediment availability, rainfall distribution and flow dynamics play, among other parameters, has been studied for a long time (e.g., Coe et al., 2008; Guthrie et al., 2010; Berger et al., 2011; Schürch et al., 2011; Abancó and Hürlimann, 2014; Theule et al., 2015), and has served to extrapolate these findings to volcanic conditions.

Previous studies found that the highest erosion rates in river basins $\left(10^{5}-10^{6} \mathrm{~m}^{3} \mathrm{~km}^{-2} \mathrm{yr}^{-1}\right)$ correspond to active volcanoes under humid climate (Milliman and Syvitski, 1992; Walling and Webb, 1996; Major et al., 2000). As observed by Lavigne (2004), for these types of volcanoes, the efficiency of erosion is a consequence of rain-triggered lahars that develop during the rainy season; converting the estimation of sediment yield and erosion rate is a very difficult task to achieve (Lavigne, 2004; Procter et al., 2010; Pierson et al., 2011; Thouret et al., 2014). However, several studies analyze the erosion/deposition $(E / D)$ processes of active channels on volcanic environments along with the factors that controls them (Major et al., 2000; Lavigne, 2004; Berger et al., 2011; Pierson et al., 2011; Starheim et al., 2013; Thouret et al., 2014). These studies point out that the main factors affecting $(E / D)$ rates are the amount of rainfall and volume of sediments available, the hydrologic characteristics of the streambottom deposits, the flow depth, and the morphology of the channel (Mizuyama and Kobashi, 1996; Fagents and Baloga, 2006; Berger et al., 2011; Okano et al., 2012; Thouret et al., 2014). Moreover, a number of studies address the issue of identifying governing factors of debris flow entrainment, and most of them have been carried out in laboratory (Mangeney et al., 2010; Iverson et al., 2011) or mountain environments (e.g., Chen et al., 2005; Hungr et al., 2005; Guthrie et al., 2010; Berger et al., 2011; McCoy et al., 2012; Abancó and Hürlimann, 2014; Theule et al., 2015). These latter studies show large scattered results, which suggests that mechanisms governing the entrainment are complex and depend on site and flow characteristics.

At Volcán de Colima, one of the most active volcanoes in Mexico, the annual occurrence of lahars during the rainy season is a common feature that has allowed the development and dynamics of these flows to be studied. Since 2011, the formation and evolution of lahars were monitored along the Montegrande ravine, a gorge located on the southern slope of the volcano, and one of the most active ravines in laharic activity. The real-time monitoring of these phenomena has been conducted by means of a monitoring station located at $2000 \mathrm{~m}$ a.s.l. (for a detailed description of the equipment see
Vázquez et al., 2014, 2016), along with topographic profiles and field data obtained during the 2013-2014 seasons. From these data, it was possible to analyze and describe the annual sediment budget at selected sites, as well as the factors that mostly control the $(E / D)$ processes. No important volcanic activity producing pyroclastic flow deposits on the volcano slope was reported during this period, a fact that could have altered the annual sedimentation rate. The results presented here can contribute to a better definition of the mitigation strategies and hazard assessment of lahars, and a determination of the most suitable sites for lahar monitoring, as well as a better understanding of the behavior of lahars at Volcán de Colima.

\section{Morphological features of Montegrande ravine}

Volcán de Colima is an almost perfectly cone-shaped stratovolcano, and has a slope that varies between 40 and $35^{\circ}$ from the summit at $3840 \mathrm{~m}$ a.s.l., which decreases to $<10^{\circ}$ towards its base (Capra et al., 2010) at $\sim 1600 \mathrm{~m}$ a.s.l. (Fig. 1). The ravines where lahars develop annually are located in the southeastern and southwestern sector of the edifice. In this paper we will focus on Montegrande ravine which is one of the most active ravines in the formation of lahars (Fig. 1), and which has been being monitored since 2011 (Vázquez et al., 2014, 2016).

The Montegrande ravine begins where two main gullies connect at the main break in the slope of the cone (from 30 to $\sim 20^{\circ}$ ), at approximately $2400 \mathrm{~m}$ a.s.l. (e.g., the proximal zone, Fig. 1-Ia, b, and II). After this, the ravine extends $\sim 6.5 \mathrm{~km}$ in length, comprising the intermediate zone, from $\sim 2300$ to $1900 \mathrm{~m}$ a.s.l., where the slope decreases to $\sim 8^{\circ}$ (Fig. 1-I c, d, e, f, and II), and the distal zone, located from 1900 to $1600 \mathrm{~m}$ a.s.l. at the mouth of the ravine, where the main channel opens to a wide fan, where the slope decreases to $\sim 2^{\circ}$ (Fig. 1-Ig, h, and II) and lahars discharge all their loads (Fig. 1h). The ravine is formed by the erosion of Holocene debris avalanche deposits, and pyroclastic flow deposits from the 1913 Plinian eruption, with vertical walls up to $20 \mathrm{~m}$ in height and up to $70 \mathrm{~m}$ in width (e.g., Fig. 1a and b). The active channel is highly variable in width, from $20 \mathrm{~m}$ to very narrow sections of $\sim 3 \mathrm{~m}$ (Fig. 1c, d, e, f, and g), and is flanked by historic laharic terraces a few meters high (e.g., Fig. 1c). In addition, the ravine presents a complex morphology downwards, showing straight paths in some places, and in others tight turns of around $60-20^{\circ}$ (Fig. 1-I). Where the ravine ends, the power lines of Comisión Federal de Electricidad (CFE), the national power company, cross the entire width of the fan (Fig. 1-I), and because of this, during the lahar season they are prone to be damaged, as has occurred in previous years (Davila et al., 2007).

The Montegrande ravine is an ephemeral stream channel. When the rainy season begins (in June for this region; Davila et al., 2007; Capra et al., 2010), and lahars start to flow down, 

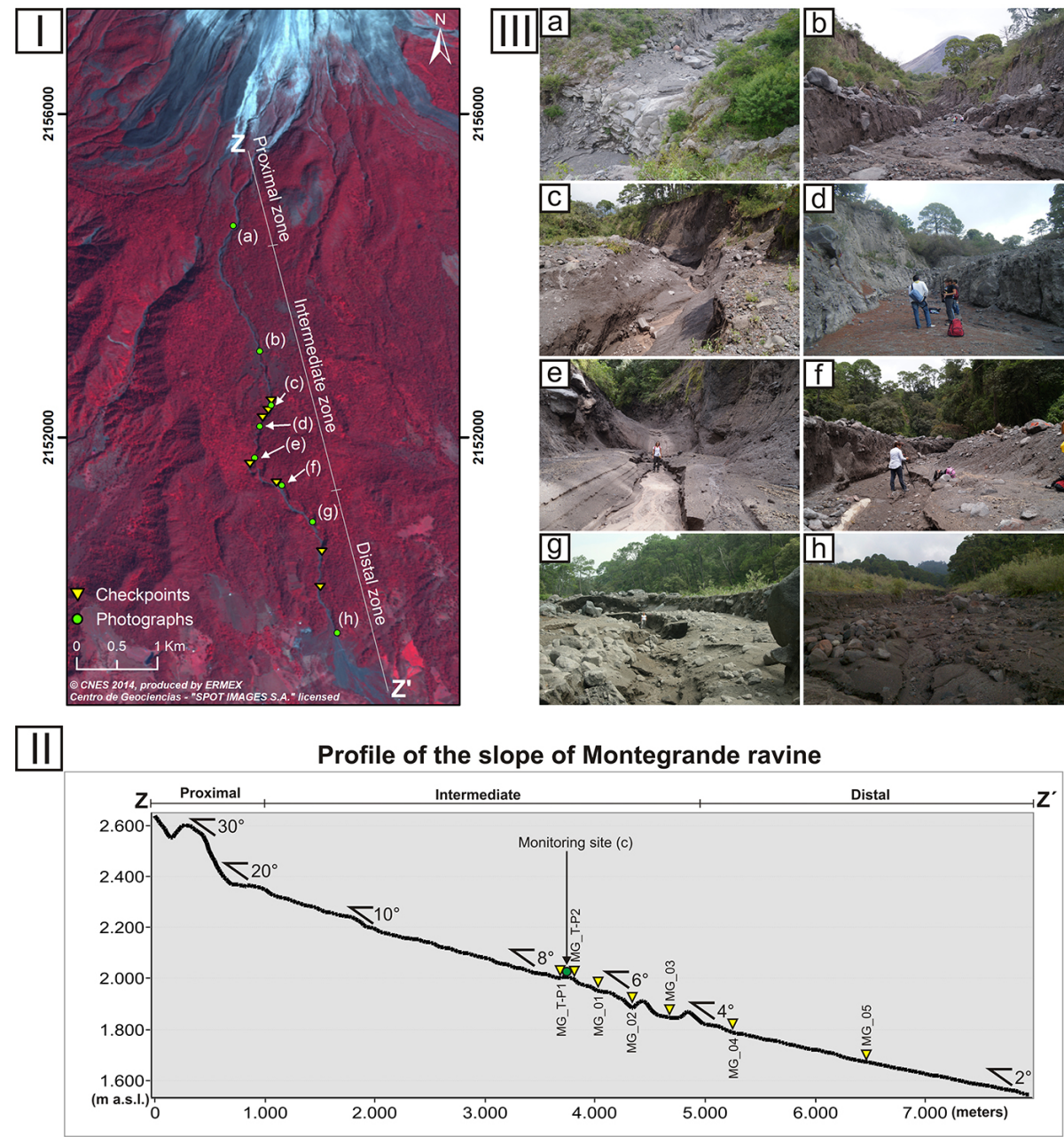

Figure 1. [I] SPOT 5 image (1, 2, 3, and 4 bands in RGB combination, $5 \mathrm{~m}$ of resolution) of Volcán de Colima showing the Montegrande ravine and the location of the checkpoints. Yellow triangles represent the location of the analyzed cross sections, green dots the location where the photos were taken: within the proximal zone (a, b), the intermediate zone (c, d, e, and f) and the distal zone (g, h). [II] Topographic profile along the ravine, showing its slope values and the location of the checkpoints and the monitoring site.

the morphology of the main channel and the terraces that flank it evolve markedly (Fig. 2a and b). Meanwhile, during the dry season, the main channel is filled up by wood debris and small failures from the banks (Fig. 2c).

\section{Methodology}

The study of the morphological changes suffered by Montegrande ravine during the 2013-2015 seasons associated with the laharic activity was carried out by taking topographic profiles perpendicular to the flow path in selected sites (e.g., Fig. 2d) and by monitoring rainfall trends in the basin. Five checkpoints were selected and their respective topographic profiles were taken on 11 and 12 June, 30 July, 11 October 2013, 12 September 2014, and 18 March 2015. These sites are numbered from MG_01 to MG_05, starting from the monitoring site at $\sim 2000 \mathrm{~m}$ a.s.l. within the intermedi- ate zone (Fig. 1-I, and II), up to the mouth of the ravine in the distal zone (Fig. 1-I). In addition, we also take into account two profiles within the portion of the monitoring site named MG_T-P1 and MG_T-P2. All profiles were taken and are presented here, looking upstream (i.e., towards the volcano crater, Fig. 2d).

For the topographic surveys, we used a laser distancemeter and for each site, reference pictures and GPS points were taken (e.g., Fig. 2d). We also leave marks on trees, walls or large clasts ( $>1.5 \mathrm{~m}$ in diameter) (Fig. $2 \mathrm{~d}$ ), in order to easily identify the sites during the field campaigns, and to use them as control marks for comparing the topographic profiles between each campaign. A HOBO RG3 water station, with a rain gauge sensor of $0.2 \mathrm{~mm}$ resolution, and sampling in 1 min intervals (Capra et al., 2010; Vázquez et al., 2016), is installed at the monitoring site (Fig. 1-Ic, and II) in order to monitor the rainfall events at Montegrande ravine lo- 
Table 1. Classification and features of the lahars that developed during the 2013 and 2014 rainy seasons, along with the first lahar of the 2015 season, on Montegrande ravine.

\begin{tabular}{|c|c|c|c|c|c|}
\hline Event & Duration (h) & $\begin{array}{l}\text { Accumulated } \\
\text { rainfall }(\mathrm{mm})\end{array}$ & $\begin{array}{l}\text { Rainfall intensity } \\
\left(\mathrm{mm} \mathrm{h}^{-1}\right)\end{array}$ & $\begin{array}{l}\text { Flow depth of } \\
\text { the FEBs }(\mathrm{m})\end{array}$ & Classification \\
\hline 11 June $2013^{*}$ & 3 & 117 & 131 & $2,3.3,3.5$ & MPE \\
\hline \multicolumn{6}{|c|}{ 11-12 June 2013 field campaign } \\
\hline 15 June 2013 & 2 & 54.4 & 112 & $1.5,3$ & MPE \\
\hline 24 July $2013^{*}$ & 1.5 & 25 & 56 & 2.5 & SPE \\
\hline \multicolumn{6}{|c|}{30 July 2013 field campaign } \\
\hline 16 September 2013 & $\begin{array}{l}2,1.8,2.5 \\
\text { (triplet lahars) }\end{array}$ & $\mathrm{N} / \mathrm{A}$ & $\mathrm{N} / \mathrm{A}$ & $\mathrm{N} / \mathrm{A}$ & MPEs \\
\hline \multicolumn{6}{|c|}{11 October 2013 field campaign } \\
\hline 2 July 2014 & 1.5 & NR & NR & 1.5 & SPE \\
\hline 3 July 2014 & 1.5 & $\mathrm{~N} / \mathrm{A}$ & $\mathrm{N} / \mathrm{A}$ & 1.3 & MPE \\
\hline 4 July 2014 & 2 & 7.4 & 19 & $<1$ & SPE \\
\hline $\begin{array}{l}7 \text { July } 2014 \\
\text { (the twin lahars) }\end{array}$ & $1.5,1.5$ & $7.8,18.6$ & $31.5,26$ & $1.5,1.8$ & MPEs \\
\hline 15 July 2014 & 2 & 3.4 & 6 & 1.5 & MPE \\
\hline 6 August 2014 & 1.5 & 14 & 95 & $\mathrm{~N} / \mathrm{A}$ & MPE \\
\hline \multicolumn{6}{|c|}{12 September 2014 field campaign } \\
\hline 17 March 2015 & $1.5,1.3$ & $\mathrm{~N} / \mathrm{A}$ & $\mathrm{N} / \mathrm{A}$ & $\mathrm{N} / \mathrm{A}$ & MPE \\
\hline \multicolumn{6}{|c|}{18 March 2015 field campaign } \\
\hline
\end{tabular}

cally. However, and as stated by Capra et al. (2010), rainfall episodes are often localized, and sometimes the rains that trigger the lahars are not recorded at the monitoring site. Despite this uncertainty, a global analysis clearly can distinguish the characteristics of rainfall that trigger lahars (Capra et al., 2010), as will be discussed below.

Morphological changes are compared here based on the results of topographic surveys. We analyze and classify a total of 15 flows which occurred during the 2013-2015 seasons (Table 1), following the methodology described in Vázquez et al. (2016), which is based on monitoring data that are gathered at Montegrande monitoring site and that identify them as single-pulse events (SPEs), and multi-pulse events (MPEs). The SPEs are characterized by a flow that lasts 1$1.5 \mathrm{~h}$ and develops a single front enriched in blocks (FEBs), followed by diluted surges (DSs), whereas the MPEs present more than one FEB interspersed by a sustained flow that shows changes in flow discharges (DSs) and lasts up to $3 \mathrm{~h}$, ending with a prolonged streamflow (Vázquez et al., 2016). In Table 1, a summary of the 15 lahars that developed during this time is presented. Maximum flow depth at the monitoring site was also estimated for the lahars with available im- ages. No more events were detected during the 2013-2015 period analyzed here.

Only for the 11 June 2013 lahar were topographic surveys performed the day before and after the event. In the other cases, profiles mostly take the annual season of lahars into account (Table 1). For example, after the 11 June lahar and before the 30 July survey, two lahars formed; after these and until the next field campaign on 11 October, an MPE event named "triplet lahars" (see Table 1) took place; it was formed of three lahars during the same day, though these were separated by some hours. During the 2014 season, seven lahars developed until the field campaign on 12 September, after which no more lahars formed in 2014. The first event of the following season occurred on 17 March 2015 and the topographic profiles were measured the day after. Thus, the morphological changes described in the following sections are related to the beginning and the end of the 2013-2015 seasons.

To quantify the $E / D$ rate, a discrete areal value was computed for each section and used to calculate it (e.g., Fig. 3a and b), after an MPE (such as the 11 June 2013, Figs. 3c, d, and 4) and seasonally (Fig. 5), in order to estimate the 2013 and 2014 annual balances (e.g., Fig. 6). For each checkpoint, 


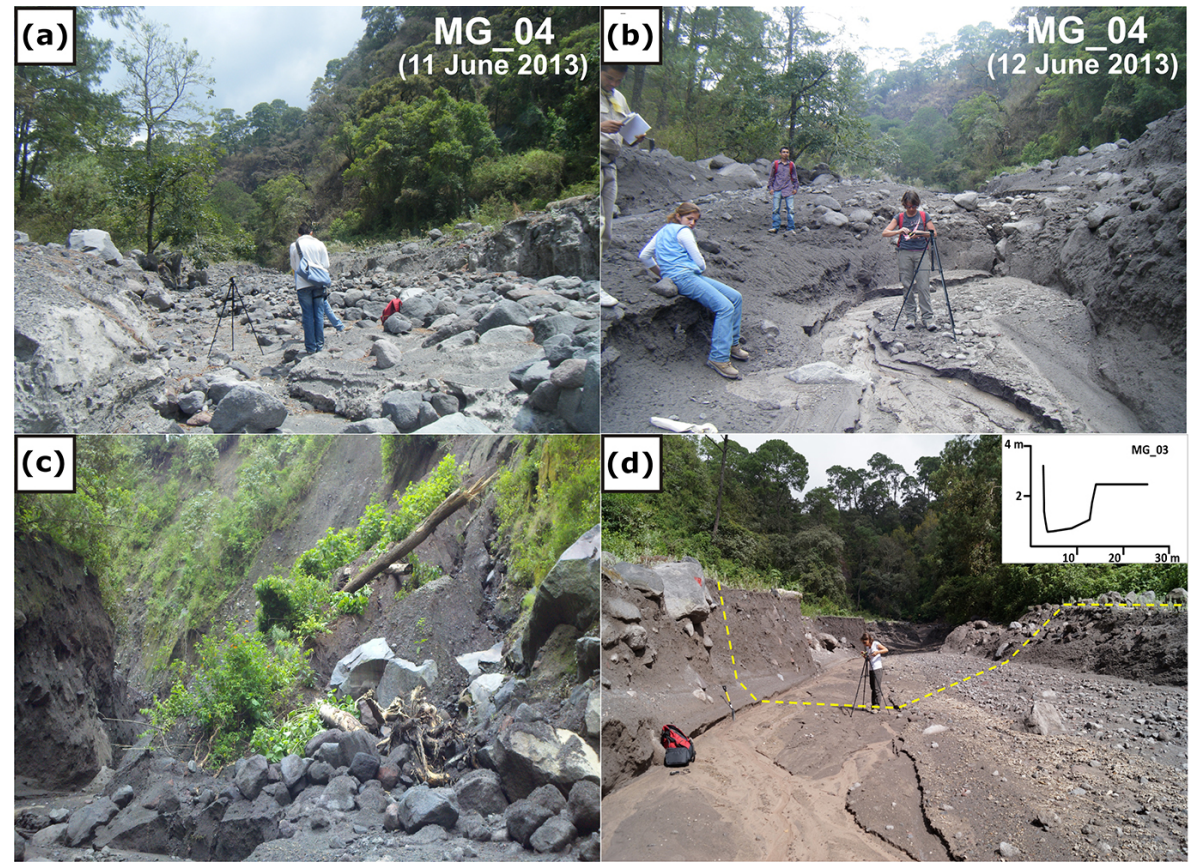

Figure 2. Photographs showing the main morphological features of Montegrande ravine and the changes due to laharic activity. (a) Photo of the morphology at MG_04 checkpoint on 11 June 2013 (at the beginning of the rainy season, and before the development of the lahar) and (b) on 12 June 2013, a day after the lahar, showing the erosion caused by the flow. (c) Trees and debris obstructing the main channel of the ravine during the dry season due to small landslides. (d) Photo of one of the checkpoints, with the sketched profile shown by a hatched yellow line, and the corresponding measured profile.
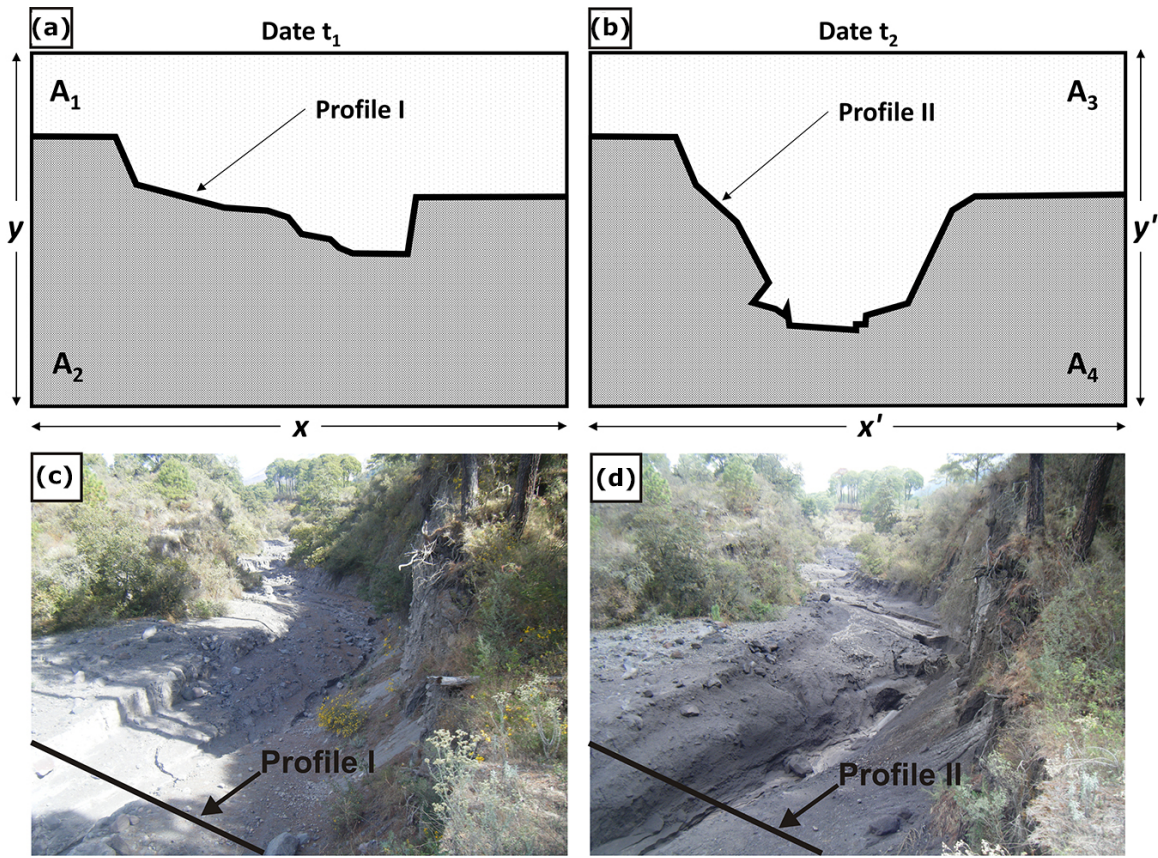

Figure 3. Graphic representation of the parameters used in the methodology to determine the $E$ (erosion) and $D$ (deposition) rates within the profiles; and photos taken at the monitoring site of Montegrande ravine, before and after the 11 June 2013 lahar. (a) Representation of the topographic profile during date $\mathrm{i}$, and the parameters needed to determine AT $=\mathrm{A} 1+\mathrm{A} 2$. (b) Representation of the topographic profile changed during date ii, and the variation of the parameters needed to determine the areal values. (c) Image of the active channel being monitored on 11 June 2013. (d) Image of the channel on 12 June 2013. 


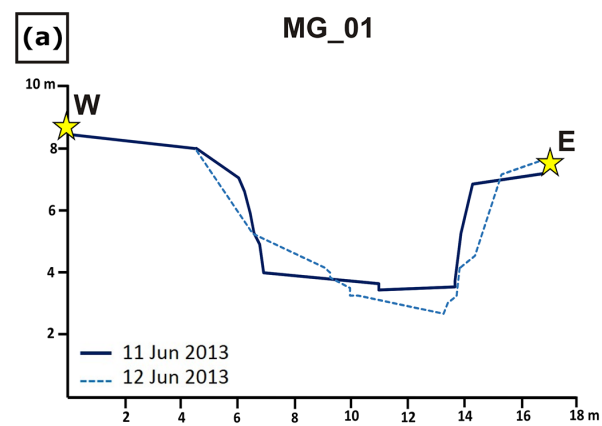

(b) MG_02
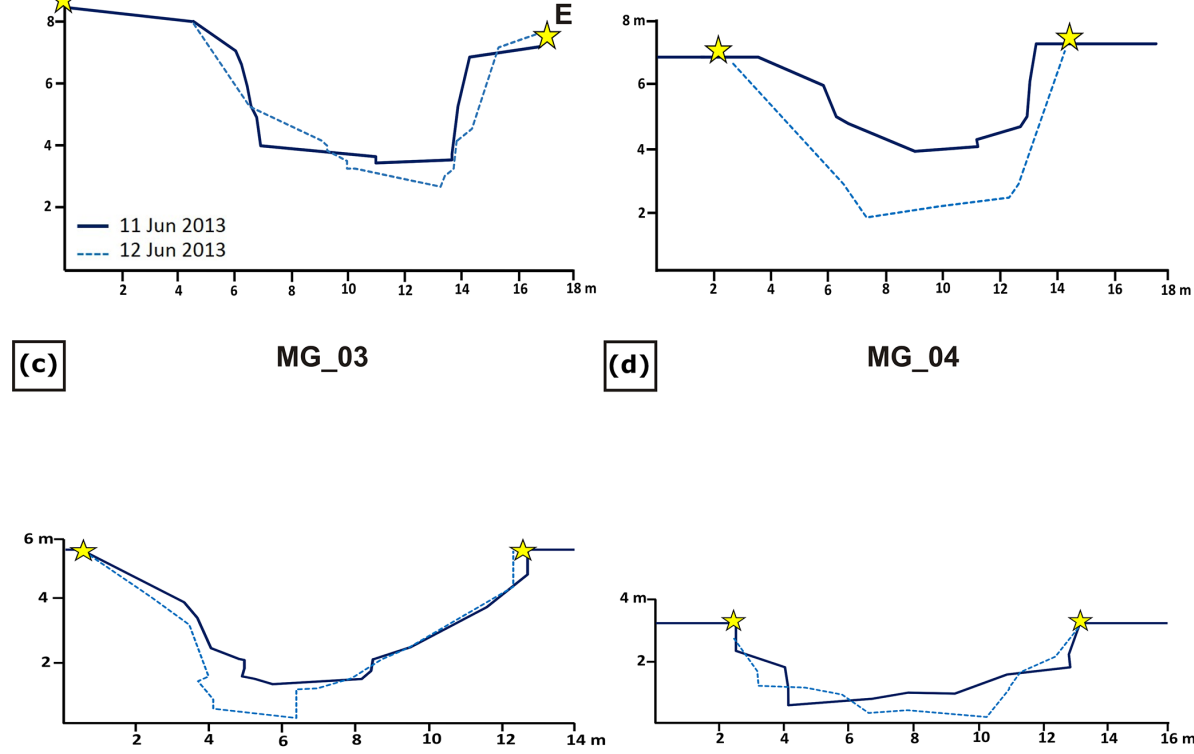

(d)

MG_04

(e) MG_05

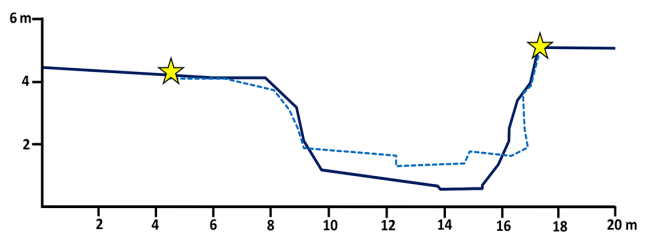

Figure 4. Cross-section profiles before (bold blue lines) and after (hatched lines in light-blue) the 11 June 2013 lahar for the following checkpoints (Fig. 1 for location): (a) MG_01, (b) MG_02, (c) MG_03, (d) MG_04, (e) MG_05. All the profiles were taken facing upstream of the channel.

the topographic profiles are superimposed to qualitatively observe channel variation in depth and width during the 20132015 seasons (Fig. 5). To do so, the topographic profiles were embedded in a rectangle of a known area (Fig. 3a and b), and the $(E / D)$ rates were determined according to the following statements (Fig. 3a and b).

1. During date $\mathrm{i}$ and date ii for the same site: $x=x^{\prime}$ and $y=y^{\prime} ;$ hence $A_{T}=x \cdot y=100 \%$.

2. During date i, $A_{1}+A_{2}=A_{T}=100 \%$; also, during date ii, $A_{3}+A_{4}=A_{T}$; hence $A_{1}+A_{2}=A_{3}+A_{4}=100 \%$.

3. There will be erosion $(E)$ if between date $\mathrm{i}$ and date ii, $A_{3}>A_{1}$ and $A_{4}<A_{2}$.

4. There will be deposition $(D)$ if between date $\mathrm{i}$ and date ii, $A_{3}<A_{1}$ and $A_{4}>A_{2}$.
From these remarks, the areal values $A_{T}, A_{1}, A_{2}, A_{3}$ and $A_{4}$, along with the rates $E$ and $D$, were estimated for the dates reported in Table 2.

\section{Results}

\subsection{Morphology of Montegrande ravine before and after the 11 June 2013 lahar}

The systematic surveying of the topographic profiles over the checkpoints in Montegrande started in 2013 after the 11 June 2013 lahar, described and classified by Vázquez et al. (2016) as an MPE (Table 1). It was the first lahar of the 2013 season, and has been one of the biggest events recorded in the ravine since 2011. It consisted of a flow that lasted approximately $3 \mathrm{~h}$, and presented several FEBs with maximum flow depth of $3.5 \mathrm{~m}$ at the monitoring point, followed by DSs. The 

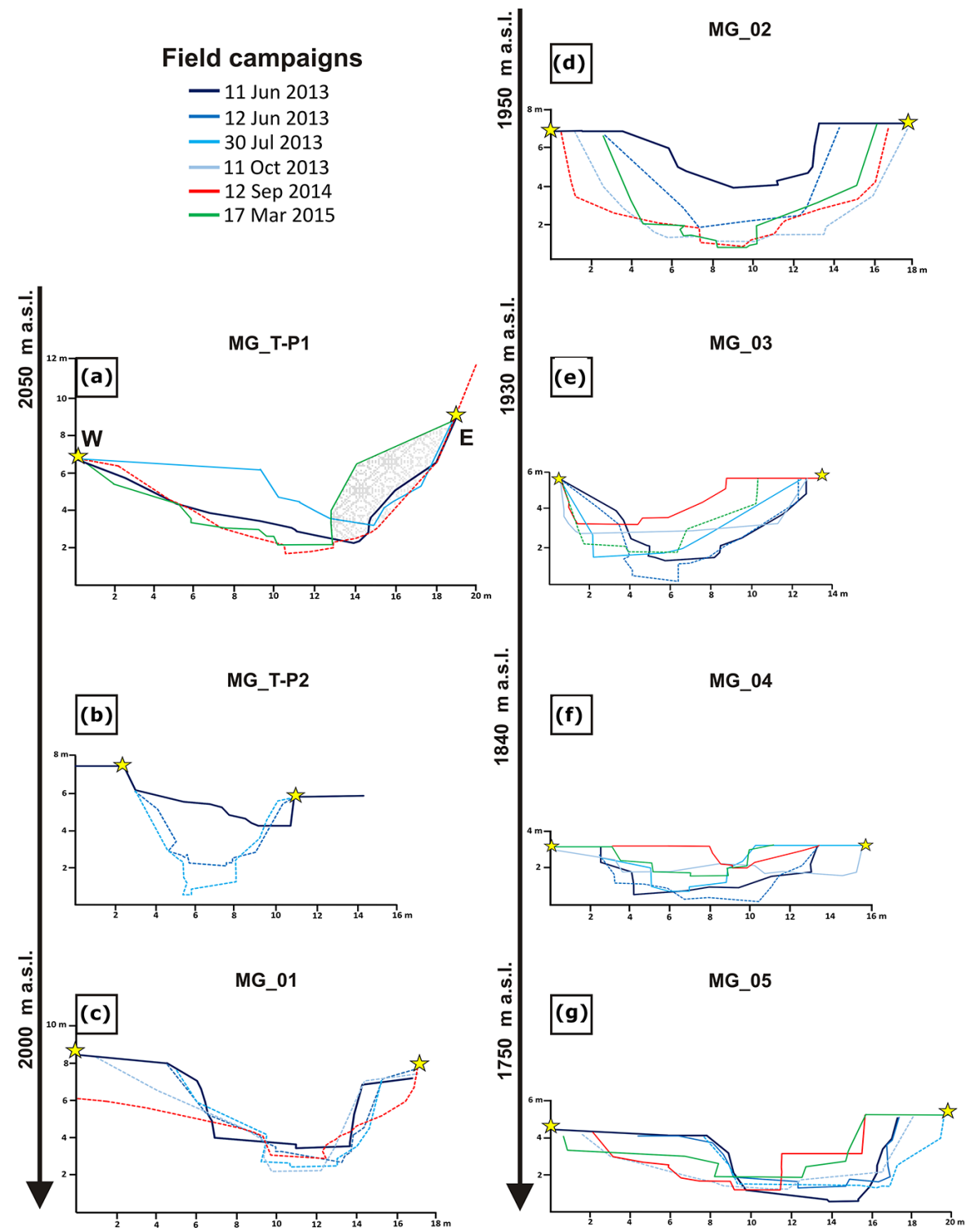

Figure 5. Comparative cross-section profiles of the checkpoints in Montegrande ravine, according to the field campaigns (Fig. 1 for location). (a) MG_T-P1, (b) MG_T-P2, (c) MG_01, (d) MG_02, (e) MG_03, (f) MG_04, and (g) MG_05. The dotted lines represent erosion, and lines represent deposition. The blue colors are related to the 2013 season, while the red and green lines refers to the 2014 and 2015 season respectively.

total rainfall associated with this lahar was $117 \mathrm{~mm}$, which accumulated in $\sim 2.2 \mathrm{~h}$ with a maximum peak intensity of $131 \mathrm{~mm} \mathrm{~h}^{-1}$ (Table 1). For this lahar, we took profiles the day before and the day after (Figs. 3c, d and 4) the event, which allowed us to outline the $E$ and $D$ rates qualitatively and quantitatively (Table 2), and which served as an example of the effects of an MPE under extreme hydrometeorological conditions.

In general, the MPE of 11 June 2013 eroded the channel bed of the ravine by $1 \mathrm{~m}$ depth on average, as can be observed in Fig. 3d, and from the profiles of checkpoints MG_01, MG_02, and MG_03 (Fig. 4a, b, and c, respectively). How- ever, from the profiles of MG_04 and MG_05 sites (Figs. 4d and e), it is clear that both $E / D$ processes were acting simultaneously. In fact, on checkpoint MG_05, the lahar left a final deposit that filled up the channel bed by at least $1 \mathrm{~m}$, but eroded the right later terrace. In general, along the ravine, erosion was more predominant in the channel bed than in the walls; however in some portions of the ravine, the erosion tends to wash away one side of the channel more preferentially than the other, developing a lateral migration of the channel axis (e.g., Fig. 4a and c).

The width of the active channel also varied after the 11 June 2013 lahar, becoming $\sim 2 \mathrm{~m}$ wider, especially in 
Table 2. Channel morphology at checkpoints, in relation to the $E / D$ ( $E$ in bold, $D$ in italics) rates, flow depths and annual rainfall for the 11 June 2013 lahar and the 2013-2014 seasons.

\begin{tabular}{lllllll}
\hline Checkpoint transect & MG_01 & MG_02 & MG_03 & & \\
\hline Mean slope & $8^{\circ}$ & $8^{\circ}$ & $6^{\circ}$ & $5^{\circ}$ & $4^{\circ}$ & \\
\hline
\end{tabular}

MG_01 and MG_02 sites (Fig. 4a and b), but to a lesser extent $(<1 \mathrm{~m})$ in the other sites (Fig. $4 \mathrm{c}, \mathrm{d}$, and e).

\subsection{Morphological evolution of Montegrande ravine within the 2013-2015 field campaigns}

Besides the MPE of 11 June 2013, three more lahars were developed during the 2013 rainy season (one of them being the triplet lahars, Table 1), for which additional observations are provided here. In 2014, more than five flows were observed, classified and analyzed, and the annual balance is presented here based on a survey before and after the season. Finally, for 2015, only data gathered after the first lahar (which was an MPE) of the season are described here (Figs. 5 and 6 and Table 1).

Figure 5 shows the profiles of the channel bed of Montegrande ravine, from the monitoring site (at $\sim 2050 \mathrm{~m}$ a.s.l., Fig. 5a) towards the mouth of the ravine (at $\sim 1750 \mathrm{~m}$ a.s.l., Fig. $5 \mathrm{~g}$ ). In all profiles, the same color corresponds to the same year, and the gradient of its color corresponds to different field campaigns. The segmented lines represent an erosion-dominated regime with respect to the previous profile, while the continuous lines represent a depositiondominated regime (Fig. 5).

The first checkpoint (MG_T-P1) is located within the segment of the channel that is being monitored by the video camera (e.g., Figs. 1c, 3c, and d). In this site, the channel morphology does not change significantly through the season. Small variations of the channel axis position are observed, which tends to migrate to the left side of the bank, towards the wall of an old terrace (Fig. 5a). After the event that occurred on 17 March 2015, the channel becomes narrower (from $\sim 14$ to $\sim 12 \mathrm{~m}$ ) due to a new small terrace de- velopment along the left bank, and to a small collapse of the right wall which occurred during the dry season (Fig. 5a).

Checkpoint MG_T-P2 (Figs. 1-I and 5b), situated $\sim 20 \mathrm{~m}$ downstream from MG_T-P1, shows an increase in depth of the channel from June to July 2013 , from $\sim 1.5$ to $\sim 5 \mathrm{~m}$ (Fig. 5b). For this checkpoint, we only took the topographic profiles during the 2013 season since in 2014 the exact location of this site was not recognizable.

The MG_01 checkpoint is located $\sim 80 \mathrm{~m}$ downstream from the monitoring site (Fig. 1-I), shows a progressive increase in depth by almost $2 \mathrm{~m}$ (Fig. $5 \mathrm{c}$ ), and becomes narrower, from $7 \mathrm{~m}$ wide at the beginning of the 2013 season to $\sim 2 \mathrm{~m}$ wide at the end of the season. It is also evident that the terraces that flank the active channel were eroded by more than $2 \mathrm{~m}$ in depth (Fig. 5c) during the 2013-2014 seasons.

The next checkpoint (MG_02, Fig. 5d) is located approximately $750 \mathrm{~m}$ downstream from the MG_01 site (Fig. 1-I), where the channel path is almost rectilinear and has a regular width of $\sim 10 \mathrm{~m}$. As can be observed from the overlapping of the profiles (Fig. 5d), the process of erosion dominates at this site, deepening the channel bed by almost $4 \mathrm{~m}$, and extending its width up to $15 \mathrm{~m}$, but maintaining the main axis in the same place (Fig. 5d).

The subsequent checkpoint MG_03 (Fig. 5e), situated $300 \mathrm{~m}$ downstream (Fig. 1-I), marks the beginning of an almost straight path of $\sim 1200 \mathrm{~m}$ downwards, where the ravine widens from $\sim 15 \mathrm{~m}$ to $>30 \mathrm{~m}$, and the vegetated walls become steeper ( $>30 \mathrm{~m}$ height). Here the profiles (Fig. 5e) present alternation of $E / D$ processes within a narrow active channel of $\sim 12 \mathrm{~m}$ width. The erosion dominated up to 30 July 2013; but at the end of the 2013 season, the channel became wider and was filled up with more than $2 \mathrm{~m}$ of sediment. By September 2014, a new terrace was formed on 

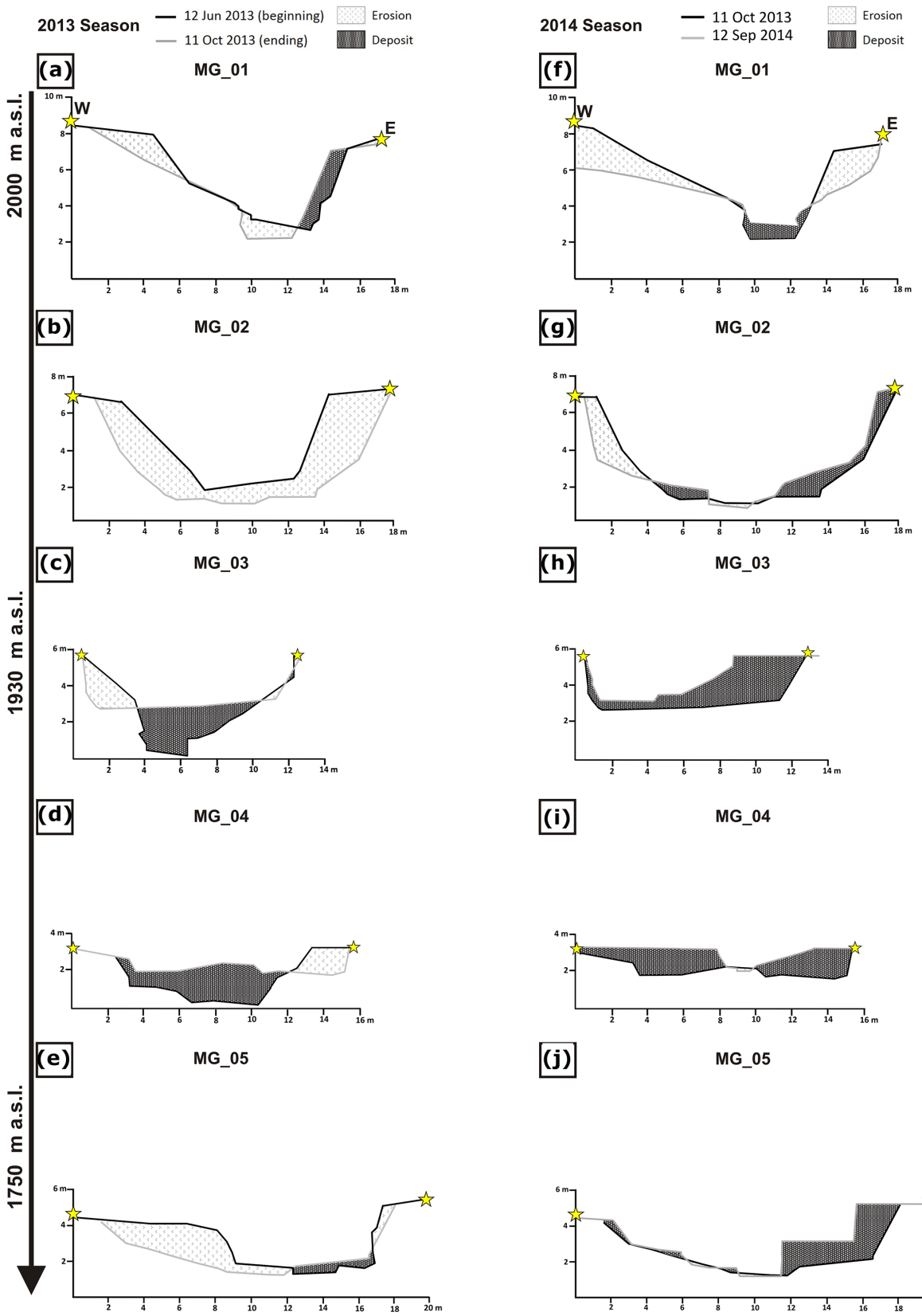

(i) MG_04

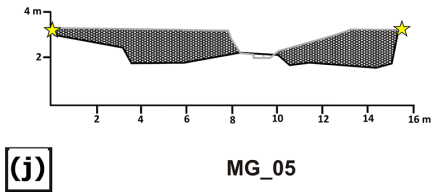

Figure 6. Annual balances during 2013 and 2014 seasons of the $E / D$ processes from the cross-section profiles of the checkpoints at Montegrande ravine (Fig. 1 for location). For the 2013 season: (a) MG_01, (b) MG_02, (c) MG_03, (d) MG_04, and (e) MG_05. For the 2014 season: (f) MG_01, (g) MG_02, (h) MG_03, (i) MG_04, and (j) MG_05. The light fill patterns represent the eroded area within the active channel and the darker fill patterns represent deposition.

the right side of the channel, narrowing its previous width $(\sim 12 \mathrm{~m})$ by $\sim 2.8 \mathrm{~m}$, and was deeply eroded by the $17 \mathrm{March}$ 2015 lahar, showing a tendency to recover its initial morphology (i.e., that from 11 June 2013, Fig. 5e) but moving the channel axis to the left side.

The MG_04 checkpoint is located approximately $800 \mathrm{~m}$ downstream from the MG_03 site, just before the path of the ravine makes a turn into another straight segment (Fig. 1-I).
At this site, the changing morphology of the channel is due again to a combination of $E / D$ processes (Fig. $5 f$ ). After the 11 June 2013 lahar, the channel was progressively filled up, mostly by the accretion of the lateral terraces that narrowed the channel, from $\sim 10$ to $\sim 7 \mathrm{~m}$. After 30 July 2013 , these newly formed terraces were eroded by the end of the 2013 season, resulting in a channel $15 \mathrm{~m}$ wide (Fig. 5f). During 2014, depositional processes dominated by filling the chan- 


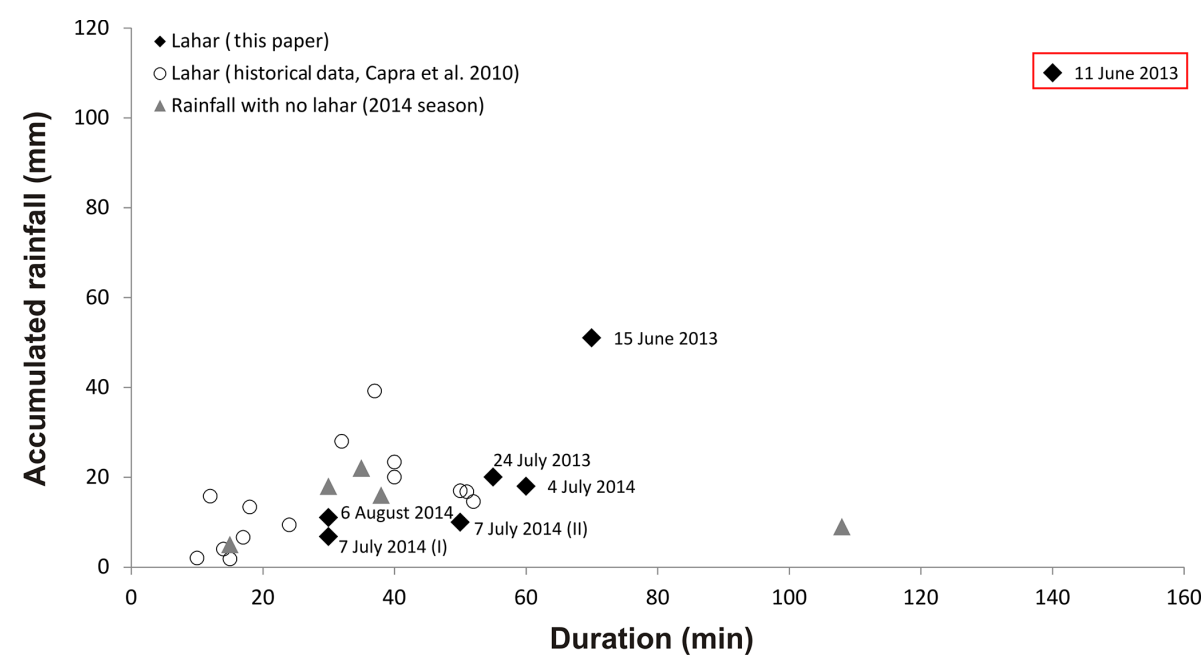

Figure 7. Comparative plot of accumulated rainfall vs. duration of historic and recent events that triggered lahars at Volcán de Colima. The black diamonds represent the data from this paper (2013-2015), and the extraordinary event of 11 June 2013 is denoted by a red box. The historical data (Capra et al., 2010) are represented with empty circles and refer to 2007-2009 years. The gray triangles represent a number of rainfall events that occurred during the 2014 season and that did not trigger a lahar.

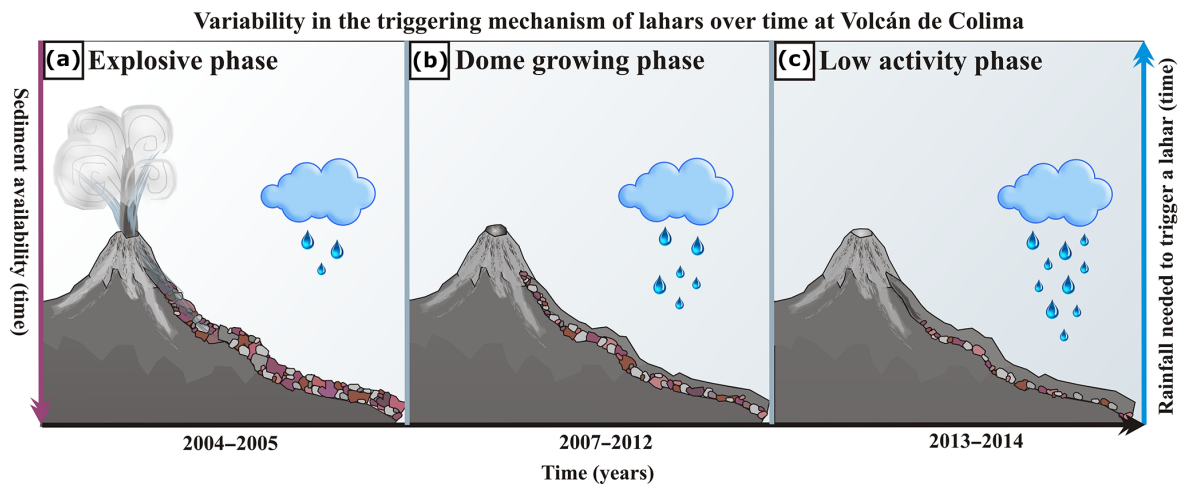

Figure 8. Conceptual model of the variability in the conditions needed to trigger a lahar over time at Volcán de Colima. (a) After the main explosive phase during 2004-2005, the slopes of the volcano were filled with material, and the rate of rainfall needed to trigger a lahar was minor. (b) During the dome growing phase (from 2007 to 2012), the amount of material decreased, while the amount of rainfall needed to trigger lahars was increasing over time. (c) Finally, during the phase of the lowest eruptive activity (from 2012 to 2015), the rate of material available to form lahars was diminishing, while a major quantity of rainfall was needed to trigger the flows.

nel of which the main axis migrated to the right, to recover a morphology in 2015 similar to the main channel shape at the beginning of the 2013 season. (i.e., 11 June 2013, Fig. 5f).

The morphology of the last checkpoint (MG_05), located $\sim 650 \mathrm{~m}$ downstream (Fig. 1-I), is also the result of a combination of $E / D$ processes. Similarly to checkpoints MG_03 and MG_04, the morphology of the channel tends to be recovered (Fig. $5 \mathrm{~g}$ ) but with a lateral migration of the main axis towards the left side through the season. After the 11 June 2013 lahar, the active channel continues to be filled up by the successive flows (Fig. $5 \mathrm{~g}$ ), decreasing its depth by about $2 \mathrm{~m}$, as observed by the 30 July campaign. By 11 October 2013, the channel suffered a major morphological change, with a widening from $\sim 7$ to $\sim 18 \mathrm{~m}$, and a deepening of the chan- nel bed $1 \mathrm{~m}$ in the central axis (Fig. 5g). During the 2014 season and from the evidence of the 18 March 2015 campaign, it could be observed that the lateral terraces were built up again, and the morphology of the middle portion of the channel tends to be recovered (Fig. $5 \mathrm{~g}$ ).

\subsection{Annual $E / D$ balance in Montegrande ravine}

\subsubsection{The 2013 season}

During 2013, five lahars were detected on the Montegrande ravine (four MPE and one SPE), and their hydrological characteristics are listed in Table 1. Total rainfall in Montegrande during 2013 was up to $580 \mathrm{~mm}$, and the 11 June 
event corresponds to an exceptional accumulated rainfall of $117 \mathrm{~mm}$ (Fig. 7).

At checkpoints MG_01 and MG_02 erosion dominates with $\sim 12 \%$ of erosion of the channel bed on average (Fig. 6 a and $b$, Table 2), mainly on the main axis of the channel. At the end of the 2013 season, the depth of the channel at checkpoint MG_01 was $2 \mathrm{~m}$ deeper than at the beginning (Figs. 5c and $6 \mathrm{a}$ ), and the channel width became wider, from $\sim 7$ to $\sim 15 \mathrm{~m}$ (Figs. 5c and 6a). At checkpoint MG_02 (Fig. 6b), the level of erosion was lower, deepening the channel bed by $\sim 2.5 \mathrm{~m}$ and widening it up to $6 \mathrm{~m}$ at the end of the season (Figs. 5d and 6b).

In the subsequent checkpoints (MG_03 to $M G_{-}$05, i.e., Fig. 6c-e) located downstream of the ravine, the rate of $E / D$ was more or less balanced (Table 2). At checkpoint MG_03 (Fig. 6c), at the end of the 2013, the channel was filled by sediments up by $2 \mathrm{~m}$ thick, reaching an $11 \mathrm{~m}$ width by the erosion on lateral walls.

At MG_04 checkpoint the rate of deposition was larger according to the values in Table 2, even though, as can be seen in Fig. $6 \mathrm{~d}, E / D$ rates are present within the profiles. The main change in the morphology of the site was the widening of the channel, from $\sim 10 \mathrm{~m}$ (on 11 June, Figs. $5 \mathrm{f}$ and $6 \mathrm{~d}$ ) to $\sim 13 \mathrm{~m}$ at the end of the season, but with an accretion of the channel bed of up to $2 \mathrm{~m}$. It is worth observing that the widening of this part of the channel was preferentially towards the right bank of the bed axis (Fig. 6d).

Finally, at checkpoint MG_05 (Fig. 6e), the level of erosion during the 2013 season was more evident, with a value of $\sim 8 \%$ that corresponds to the widening of the channel from $\sim 8 \mathrm{~m}$ to $\sim 16 \mathrm{~m}$ (Fig. 6e), but with a deposit in the middle axis of $\sim 0.5 \mathrm{~m}$ in thickness by the end of the season.

\subsubsection{The 2014 season}

During the 2014 season, the total rainfall in Montegrande ravine was $\sim 540 \mathrm{~mm}$. In comparison with the 2013 season, the changes in the morphology of the checkpoints were dominated rather by the process of deposition than by erosion (Fig. 6), even though seven lahars were developed during 2014 (five MPEs and two SPEs, Table 1).

In general, at checkpoints MG_01 and MG_02 (Fig. 6f and $\mathrm{g})$, the rate of erosion was higher than in the downstream checkpoints (MG_03, MG_04, and MG_05, Fig. 6h-j, respectively), but not that high in comparison to the 2013 season (Fig. 6a-e, Table 2).

At checkpoint MG_01 (Fig. 6f), the erosion was mainly focused on the walls of the terraces that flank the channel axis, eroding $\sim 8 \%$ of the material, diminishing its height by $2 \mathrm{~m}$, but conserving the active channel width of $\sim 2.5 \mathrm{~m}$ with a final deposit of $\sim 1 \mathrm{~m}$ in thickness (Fig. 6f). On the other hand, at checkpoint MG_02, both E/D are present, (Fig. 6g), with a final deposition rate of $0.7 \%$ (Table 2) and conserving the main morphology through the season, i.e., a wide channel ( $\sim 16 \mathrm{~m}$ width), flanked by terraces of $5 \mathrm{~m}$ height (Fig. $6 \mathrm{~g}$ ).
In contrast to the observed balance on $E / D$ rates for the MG_01 and MG_02 sites, at the successive checkpoints, the deposition process dominates. For instance, at site MG_03 (Fig. 6h), the channel width reduced from $\sim 11$ to $\sim 8 \mathrm{~m}$, due to $18.5 \%$ of deposition within the channel bed forming a new terrace on the right side of the channel. Similarly, at checkpoint MG_04 (Fig. 6i), the width of the channel reduced from $\sim 16$ to $\sim 5 \mathrm{~m}$, because of the $\sim 20 \%$ of deposition (Table 2) left in the channel bed, with the formation of new terraces along the flank of the active channel (Fig. 6i). Finally, at checkpoint MG_05 (Fig. 6j), a morphology similar to the MG_03 site can be observed, where new material was deposited preferentially on the right side of the channel wall $(D=9.6 \%)$, leaving vertical steps and narrowing the channel from $\sim 16$ to $\sim 14 \mathrm{~m}$ (Fig. 6j).

\section{Discussion}

It is well known that channel morphology controls flow depth, flow velocity and peak discharge, and that it also promotes bulking or de-bulking of lahars. According to the observations made by Doyle et al. (2011), when these flows reach a steady state, they tend to have extremely dynamic interactions with their channel and may rapidly alternate between net deposition and erosion, and thus exchange part of their sediment load. Dynamically, erosion normally occurs under a rise of the peak flow, even though the degree of erosion-related bulking depends upon the erodibility of the channel bed, bank, and related material, the shear stress applied to these surfaces, and the volume of sediment available for erosion (Pierson, 1995). Hence, a narrow channel will increase the depth of the flow, its velocity, and thus the discharge, promoting erosion, as seen at MG_01 and MG_02 checkpoints, where the channel mean width is $\sim 10 \mathrm{~m}$, and the channel is flanked by steep terraces, in comparison to the downstream sites (from MG_03 to MG_05), where the channel width is $>10 \mathrm{~m}$ on average. Conversely, deposition tends to be concentrated in sites of local sudden slope decrease (Fannin and Wise, 2001; Hürlimann et al., 2003; Hungr et al., 2005; Schürch et al., 2011), increased channel width, channel bends, or bifurcations (Doyle et al., 2011; Schürch et al., 2011).

At Montegrande ravine, field evidence shows that erosive processes dominate in the intermediate zone (i.e., checkpoint MG_01 and 02), where the slope gradient is up to $8^{\circ}$ in comparison to the more distal sites where both $E / D$ processes act because the ravine becomes wider and the slope diminishes from $\sim 6$ to $4^{\circ}$, i.e., checkpoints MG_03 to MG_05 (Fig. 1). This was evident through comparisons of portions of the ravine with similar morphology (e.g., MG_01 and MG_04 checkpoints, which recorded a straight channel $\sim 80 \mathrm{~m}$ long, bracketed by two narrow bends) but different channel bed slope, showing the depositional processes becoming more dominant towards lower slope angles (i.e., the fan of the 
ravine). This behavior is in agreement with the hydrogeomorphological model proposed by Lavigne (2001), which identifies the chief processes that shape the channel morphology in three main channel segments: (1) a proximal segment where riverbed and bank erosion is continuous (i.e., from MG_01 to MG_02), (2) an unsteady transitional zone, where erosional processes alternate with depositional processes (i.e., from MG_03 to MG_05), and (3) a distal segment where sediment deposition is continuous (in this case, the alluvial fan of Montegrande ravine).

Based on these results, the channel bed slope represents the first morphological parameter in controlling the $E / D$ rates at Montegrande ravine; erosion is prevalent where the channel bed slope is higher than $8^{\circ}$, while depositional processes dominate where the channel bed slope is smaller than $5^{\circ}$. This latter slope value represents a higher value than that observed in Ruapehu of $\sim 2.7-0.7^{\circ}$ (Fagents and Baloga, 2006) or the $<1.2^{\circ}$ found by Pierson (1995) for snow-clad volcanoes, but a similar value to those observed in Popocatépetl volcano (i.e., $<6.5^{\circ}$, Capra et al., 2004; MuñozSalinas et al., 2008, 2009). On the other hand, the dominant erosional behavior of lahars above $8^{\circ}$ is also consistent with observations made in other volcanic environments (e.g., Procter et al., 2010) and in Alpine basins affected by debris flows (e.g., Berger et al., 2011; Schürch et al., 2011; Theule et al., 2015).

The second morphological parameter that affects $E / D$ processes at Montegrande ravine is the cross-section width. In Montegrande, at distal sections (MG-04 and MG-5), E/D processes alternate and appear to be controlled by both the channel width variation and the decrease of the channel bed slope angle. However, our observations dictate that erosion dominates as the channel reaches a critical width, after which deposits start forming new terraces along the channel wall (e.g., Fig. $5 \mathrm{f}$ and g). When the channel narrows anew, erosion takes place again. This cyclic behavior of $E / D$ regimes controlled by the channel morphological changes has been previously observed and quantified by Doyle et al. (2009), Berger et al. (2011), and Schürch et al. (2011). In particular, Schürch et al. (2011) supported this remark by studying the scouring effects of debris flows at Illgraben, in the Swiss Alps. According to their measurements, substantial erosion is more likely when flow depth increases. Events with front heights $>2.3 \mathrm{~m}$ were all erosive; meanwhile the events with front heights $<2.7 \mathrm{~m}$ were mainly depositional. Similar behavior was observed in the Montegrande ravine, where the flows that occurred during the 2013 season had front heights of more than $2 \mathrm{~m}$ and up to $3.5 \mathrm{~m}$ (Table 1), presenting a regime that was mainly erosive, especially considering the 11 June lahar alone (Figs. 3 and 4). During the 2014 season, the flows presented mean front heights of $\sim 1.5 \mathrm{~m}$ (Table 1), being mainly depositional. These values clearly correlated with the annual $E / D$ rate observed during the 2013-2014 season. The 11 June 2013 lahar represents an exceptional event that was erosive almost all along the ravine. This lahar was asso- ciated with an extraordinary rainfall event $(117 \mathrm{~mm}$ of accumulated rain, Table 1) that developed a large flow depth up to $3.5 \mathrm{~m}$, and highly erosive flow all along the Montegrande ravine. Similar exceptional events have been previously observed in the same ravine during the Jova hurricane, which also developed a high-magnitude lahar that deeply eroded the channel (Capra et al., 2013).

The joint effect of two other parameters acting together, i.e., the accumulated rainfall and the sediment availability, is the last fundamental factor that governs $E / D$ processes at Montegrande ravine. An active volcano has a natural slope where sediment supply is regulated by the frequency and magnitude of the explosive activity. After a main eruption, lahar frequency increases due to the immediate reworking of pyroclastic material (Manville et al., 2009), even in correspondence to low accumulated rains (Capra et al., 2010), until it progressively decreases in the following years, as observed at Volcán de Colima (Davila et al., 2007; Capra et al., 2010) and other volcanoes (Lavigne, 2004; Thouret et al., 2014; Major et al., 2016). These factors, along with the physical features of the flows (i.e., sediment load, depth, volume, discharge, etc.), will control the morphological evolution of the ravine, until the landscape response to the volcanic perturbation returns to background conditions (Manville et al., 2009; Thouret et al., 2014). This dynamic is evident in Montegrande ravine, where the sediment availability has been decreasing in the last years. The eruptive phase that occurred in 2004-2005 is the last significant phase of sediment supply that occurred along the volcano flanks. Block-and-ash flows (BAFs) were emplaced on main ravines up to $6.5 \mathrm{~km}$ from the crater (Macías et al., 2006; Sulpizio et al., 2010), due to the repetitive growing and collapse of the summit dome (Fig. 8a). Then, a new period of slow dome growing began in 2007 and stopped in 2010, after reaching the crater rim and spilling over in 2011 (Capra et al., 2015; Fig. 8b). Finally, a phase of low activity characterized the 2013-2014 years (Fig. 8c). Consequently, a period of 8 years (during the intraeruptive period from 2007 to July 2015; Capra et al., 2016) was needed to recover the hydrological and sedimentaryyield balance to background conditions. This dynamic is in agreement with the recovering times observed after a minor eruption (Manville et al., 2009). This means that as the volcano recovers its slope stability, more extreme rainfall events are needed to trigger a lahar. Rainfall data presented here are based only on one rain gauge, and, as observed before, rainfall can be locally concentrated. Hence, the estimation of rainfall thresholds triggering a lahar cannot be very accurate, at least for the events at the beginning of the season, which are strongly related to orographic rainfalls (high intensitieslow rain accumulation) (Capra et al., 2010). At Volcán de Colima, after the last significant eruptive phase (i.e., 20042005 years), in the succeeding years (i.e., 2007-2012), the rain episodes needed to trigger lahars were of short duration and had low accumulated rainfall values (e.g., Figs. 7 and 8a), as reported by Capra et al. (2010). However, from 2013, 
the precipitation required to trigger a lahar was of higher values of accumulated rainfall and/or longer duration (Figs. 7 and 8c). During the 2014 season, a number of rainfall events did not trigger lahars. These events had similar characteristics to those observed during the 2007-2012 period (Fig. 7), which confirms the gradual decrease of sediment availability around the volcanic edifice.

\section{Conclusion}

The systematic monitoring of the morphological changes observed in Montegrande ravine in the past years served as a starting point for the analysis of the geomorphic modifications due to post-eruptive lahars in an active channel in a volcanic environment.

Channel bed slope, cross-section width and the joint effect of sediment availability and rainfall magnitude are the main factors controlling $E / D$ processes at Montegrande ravine. In particular, the proximal and middle reaches, where the bed slope is up to $10-8^{\circ}$, are dominated by erosion, while in the distal reach $\left(5-2^{\circ}\right), E / D$ processes act simultaneously. In the distal reach of the ravine, the $E / D$ processes tend to be promoted preferentially one over the other, also depending upon the channel width between events, which in turn affects the flow depth, inducing one regime or the other. Only for extraordinary rainfall events are lahars mostly erosive all along the ravine up to the distal fan where deposition takes place.

These results can be used as a tool to foresee the effects of future laharic events in Volcán de Colima, and as a tool to improve the input parameters for the modeling of these flows along other volcanoes (e.g., the Popocatépetl volcano; see Caballero and Capra, 2014), in order to determine the hazard zonation for lahars in this volcano.

The 2013-2014 period was characterized by very low explosive activity at Volcán de Colima, during which only small rockfalls and pyroclastic flows formed at the beginning of the 2013 and at the end of 2014. As previously observed (Capra et al., 2010), lahar frequency increases right after an eruptive phase and decreases during the following years, but this study evidences that the number of events is not directly related to the $E / D$ rate, in comparison to the amount and intensity of rainfall, which still remains as the main factor in controlling flow discharge (magnitude) and duration. The volcano landscape recovered its hydrological and sediment yield equilibrium in less than 10 years, and only the largest and long-lasting lahars can catastrophically modify the ravine morphology.

A series of BAFs that occurred during the dome collapse episode of 10-11 July 2015 at Volcán de Colima dramatically changed the morphology of Montegrande ravine, filling up the main channel up to its distal fan (Capra et al., 2016), and became rectilinear, altering its geomorphic and hydrological features again. These new geomorphic conditions will probably lead to the formation of a new morphology and to a change in the characteristics of the flows of the next rainy season that will likely involve a large amount of sediment.

\section{Data availability}

Rain gauge data and images of the recorded lahars are available under a collaborative framewok between Centro de Geociencias, UNAM (L. Capra), and related Institutes, and Universities. In case of needing further information, we ask you kindly to contact directly the authors.

Acknowledgements. This work was supported by CONACyT 220786, PAPIIT-UNAM IN-105116 and SRE-CONACyT 146324 projects, managed by Lucia Capra. Thanks are expressed to the staff of Centro Nacional de Prevención de Desastres (CENAPRED) for the setup of the instrumentation at Montegrande monitoring site. Thanks are due to Penélope López for managing the Spot image acquisition from ERMEX-SPOT IMAGE S.A. We also thank all the students and colleagues who helped to take the topographic profiles during the seasons.

Edited by: G. Macedonio

Reviewed by: L. Caballero and R. Cioni

\section{References}

Abancó, C. and Hürlimann, M.: Estimate of the debris-flow entrainment using field and topographical data, Nat. Hazards, 71, 363383, doi:10.1007/s11069-013-0930-5, 2014.

Andrés de Pablo, N., Zamorano, J. J., and Blasco, J. J. S.: Evolución post-lahárica de un canal proglaciar: garganta de Huiloac (México), Bol. Soc. Geol. Mex., 66, 305-328, 2014.

Berger, C., McArdell, B. W., and Schlunegger, F.: Direct measurement of channel erosion by debris flows, Illgraben, Switzerland, J. Geophys. Res., 116, F01002, doi:10.1029/2010JF001722, 2011.

Beverage, J. and Culbertson, J.: Hyperconcentrations of suspended sediment, Am. Soc. Civ. Eng., 90, 117-126, 1964.

Caballero, L. and Capra, L.: The use of FLO2D numerical code in lahar hazard evaluation at Popocatépetl volcano: a 2001 lahar scenario, Nat. Hazards Earth Syst. Sci., 14, 3345-3355, doi:10.5194/nhess-14-3345-2014, 2014.

Capra, L., Poblete, M. A., and Alvarado, R.: The 1997 and 2001 lahars of Popocatépetl volcano (Central Mexico): textural and sedimentological constraints on their origin and hazards, J. Volcanol. Geotherm. Res., 131, 351-369, 2004.

Capra, L., Borselli, L., Varley, N., Gavilanes-Ruiz, J. C., Norini, G., Sarocchi, D., Caballero, L., and Cortes, A.: Rainfall-triggered lahars at Volcán de Colima, Mexico: Surface hydro-repellency as initiation process, J. Volcanol. Geotherm. Res., 189, 105-117, 2010.

Capra, L., Roverato, M., Gropelli, G., Sulpizio, R., ArámbulaMendoza, R., Reyes, G., Lube, G., and Cronin, S. J.: Hurricanetriggered lahars at Volcán de Colima: evidences of flow dynamic from monitoring and field survey, abstract with program IAVCEI, 1P2_3G-020, Kagoshima, Japan, 2013. 
Capra, L., Gavilanez-Ruiz, J. C., Bonasia, R., Saucedo-Giron, R., and Sulpizio, R.: Re-assessing volcanic hazard zonation of Volcán de Colima, México, Nat. Hazards, 74, 41-61, doi:10.1007/s11069-014-1480-1, 2015.

Capra, L., Macías, J. L., Cortés, A., Dávila, N., Saucedo, R., OsorioCampo, S., Arce, J. L., Gavilanes-Ruiz, J. C., Corona-Chávez, P., García-Sánchez, L., Sosa-Ceballos, G., and Vázquez, R.: Preliminary report on the July 10-11, 2015 eruption at Volcán de Colima: Pyroclastic density currents with exceptional runouts and volume, J. Volcanol. Geotherm. Res., 310, 39-49, 2016.

Chen, J., He, Y. P., and Wei, F. Q.: Debris flow erosion and deposition in Jiangjia Gully, Yunnan, China, Environ. Geol., 48, 771-777, doi:10.1007/s00254-005-0017-z, 2005.

Coe, J. A., Kinner, D. A., and Godt, J. W.: Initiation conditions for debris flows generated by runoff at Chalk Cliffs, central Colorado, Geomorphol., 96, 270-297, doi:10.1016/j.geomorph.2007.03.017, 2008.

Costa, J. E.: Physical geomorphology of debris flows, in: Developments and Applications of Geomorphology, edited by: Costa, J. E. and Fleisher, P. J., Springer, Berlin, 268-317, 1984.

Costa, J. E.: Rheologic, geomorphic, and sedimentalogic differentiation of water floods, hyperconcentrated flows and debris flows, in: Flood geomorphology, edited by: Baker, V. R., Craig Kochel, R., and Patton, P. C., John Wiley and Sons, New York, 113-122, 1987.

Cronin, S. J., Neall, V. E., Lecointre, J. A., and Palmer, A. S.: Dynamic interactions between lahars and stream flow: A case study from Ruapehu volcano, New Zealand, Geol. Soc. Am. Bull., 111, 28-38, doi:10.1130/00167606(1999)111<0028:DIBLAS>2.3.CO;2, 1999.

Davila, N., Capra, L., Gavilanes-Ruiz, J. C., Varley, N., Norini, G., and Gómez-Vazquez, A.: Recent lahars at Volcán de Colima (Mexico): Drainage variation and spectral classification, J. Volcanol. Geotherm. Res., 165, 127-141, 2007.

Doyle, E. E., Cronnin, S. J., Cole, S. E., and Thouret, J.-C.: The challenges of incorporating temporal and spatial changes into numerical models of lahars, in: 18th World IMACS/MODSIM Congress, Cairns, Australia, 2009.

Doyle, E. E., Cronin, S. J., and Thouret, J.-C.: Defining conditions for bulking and debulking in lahars, Geol. Soc. Am. Bull., 123, 1234-1246, 2011.

Fagents, S. A. and Baloga, S. M.: Toward and model for the bulking and debulking of lahars, J. Volcanol. Geotherm. Res., 111, B10201, doi:10.1029/2005JB003986, 2006.

Fannin, R. J. and Wise, M. P.: An empirical-statistical model for debris flow travel distance, Can. Geotech., J., 38, 982-994, doi:10.1139/cgj-38-5-982, 2001.

Guthrie, R. H., Hockin, A., Colquhoun, L., Nagy, T., Evans, S. G., and Ayles, C.: An examination of controls on debris flows mobility: Evidence from coastal British Columbia, Geomorphol., 114, 601-613, 2010.

Hungr, O., McDougall, S., and Bovis, M.: Entrainment of material by debris flows, in: Debris-flows hazards and related phenomena, edited by: Jabob, M. and Hungr, O., Springer, Berlin Heidelberg, 135-158, 2005.

Hürlimann, M., Rickenmann, D., and Graf, C.: Field and data monitoring of debris-flow events in the Swiss Alps, Can. Geotech. J., 40, 161-175, doi:10.1139/t02-087, 2003.
Iverson, R. M., Reid, M. E., Logan, M., LaHusen, R. G., Godt, J. W., and Griswold, J. P.: Positive feedback and momentum growth during debris-flow entrainment of wet bed sediment, Nat. Geosci., 4, 116-121, doi:10.1038/ngeo1040, 2011.

Lavigne, F.: Evolution géomorphologique de la vallée Boyong à la suite de l'éruption du 22 novembre 1994 du volcán Merapi, Java, Indonésie, Geomorphologie Suppl., 46, 123-142, 2001.

Lavigne, F.: Rate of sediment yield following small-scale volcanic eruptions: A quantitative assessment at the Merapi and Semeru stratovolcanoes, Java, Indonesia, Earth Surf. Process. Landf., 29, 1045-1058, 2004.

Macías, J. L., Saucedo, R., Gavilanes, J. C., Varley, N., VelascoGarcía, S., Bursik, M., Vargas-Gutiérrez, V., and Cortés, A.: Flujos piroclásticos asociados a la actividad explosiva del Volcán de Colima y perspectivas futuras, GEOS, 25, 340-351, 2006.

Major, J. J., Pierson, T. C., Dinehart, R. L., and Costa, J. E.: Sediment yield following severe volcanic disturbance: a two-decade perspective from Mount St. Helens, Geology, 28, 819-822, 2000.

Major, J. J., Bertin, D., Pierson, T. C., Amigo, Á., Iroumé, A., Ulloa, H., and Castro, J.: Extraordinary sediment delivery and rapid geomorphic response following the 2008-2009 eruption of Chaitén Volcano, Chile, Water Resour. Res., 52, doi:10.1002/2015WR018250, 2016.

Mangeney, A., Roche, O., Hungr, O., Mangold, N., Faccanoni, G., and Lucas, A.: Erosion and mobility in granular collapse over sloping beds, J. Geophys. Res. Earth. Surf., 115, 1-21, doi:10.1029/2009JF001462, 2010.

Manville, V., Németh, K., and Kano, K.: Source to sink: A review of three decades of progress in the understanding of volcanicastic processes, deposits and hazards, Sed. Geol., 220, 136-161, 2009.

McCoy, S. W., Kean, J. W., Coe, J. A., Tucker, G. E., Stanley, D. M., and Wasklewicz, T. A.: Sediment entrainment by debris flows: In situ measurements from the headwaters of a steep catchment, J. Geophys. Res. Earth Surf., 117, 1-25, doi:10.1029/2011JF002278, 2012.

Milliman, J. D. and Syvitski, J. P.: Geomorphic/tectonic control of sediment discharge to the ocean: the importance of small mountainous rivers, J. Geol., 100, 525-544, 1992.

Mizuyama, T. and Kobashi, S.: Sediment yield and topographic change after major volcanic activity, in: Proceedings of the Exeter Symposium, IAHS Publication, IAHS Publication 236 pp., 295-301, 1996.

Muñoz-Salinas, E., Renschler, C. S., Palacios, D., and Namikawa, L. M.: Updating cannel morphology in digital elevation models: lahar assessment for Tenenepanco-Huiloac Gorge, Popocatépetl volcano, Mexico, Nat. Hazards, 45, 309-320, 2008.

Muñoz-Salinas, E., Renschler, C. S., and Palacios, D.: A GIS-based method to determine the volume of lahars: Popocatépetl volcano, Mexico, Geomorphol., 111, 61-69, 2009.

Okano, K., Suwa, H., and Kanno, T.: Characterization of debris flows by rainstorm condition at a torrent on the Mount Yakedake Volcano, Japan, Geomophol., 136, 88-94, 2012.

Pierson, T. C.: Flow characteristics of large eruption-triggered debris flows at snow-clad volcanoes: Constraints for debrisflow models, J. Volcanol. Geotherm. Res., 66, 183-194, doi:10.1016/0377-0273(94)00070-W, 1995.

Pierson, T. C.: Hyperconcentrated flow transition process between water flow and debris flow, in: Debris flow hazards and related 
phenomena, edited by: Jakob, M. and Hungr, O., Springer Verlag, New York, 159-196, 2005.

Pierson, T. C. and Costa, J. E.: A rheologic classification of subaerial sediment-water flows, Geol. Soc. Am. Rev. Eng. Geol., 7, 1-12, 1987.

Pierson, T. C. and Scott, K. M.: Downstream dilution of a lahar, transition from debris flow to hyperconcentrated streamflow, Water Resour. Res., 21, 1511-1524, doi:10.1029/WR021i010p01511, 1985.

Pierson, T. C., Pringle, P. T., and Cameron, K. A.: Magnitude and timing of downstream channel aggradation and degradation in response to a dome-building eruption at Mt. Hood, Oregon, Geol. Soc. Am. Bull., 123, 3-20, 2011.

Procter, J., Cronin, S. J., Fuller, I. C., Lube, G., and Manville, V.: Quantifying the geomorphic impacts of a lake-breakout lahar, Mount Ruapehu, New Zealand, Geol., 38, 67-70, doi:10.1130/G30129.1, 2010.

Schürch, P., Densmore, A. L., Rosser, N. J., and McArdell, B. W.: Dynamic controls on erosion and deposition on debris-flow fans, Geol., 39, 827-830, doi:10.1130/G32103.1, 2011.

Scott, K. M.: Origins, behavior, and sedimentology of lahars and lahar-runout flows in the Toutle-Cowlitz River system, US Geological Survey Professional Paper, 1447-A, 47 pp., 1988.

Scott, K. M., Vallance, J. W., Kerle, N., Macias, J. L., Strauch, W., and Devoli, G.: Catastrophic precipitation-triggeres lahar at Casita volcano, Nicaragua: Occurrence, bulking, and transformation, Earth Surf. Proc. Landf., 30, 59-79, doi:10.1002/esp.1127, 2005.

Smith, G. A. and Fritz, W. J.: Volcanic influences on terrestrial sedimentation, Geology, 17, 375-376, 1989.
Starheim, C., Gomez, C., Daves, T., Lavigne, F., and Wassmer, P.: In-flow evolution of lahar deposits from video-imagery with implications for post-event deposit interpretation, Mount Semeru, Indonesia, J. Volcanol. Geotherm. Res., 256, 96-104, 2013.

Sulpizio, R., Capra, L., Sarocchi, D., Saucedo, R., Gavilanes-Ruiz, J. C., and Varley, N. R.: Predicting the block-and-ash flow inundation areas at Volcán de Colima (Colima, Mexico) based on the present day (February 2010) status, J. Volcanol. Geotherm. Res., 193, 49-66, 2010.

Theule, J. I., Liébault, F., Laigle, D., Loye, A., and Jaboyedoff, M.: Channel scour and fill by debris flows and bedload transport, $\mathrm{Ge}-$ omorphol., 243, 92-105, 2015.

Thouret J. C., Oehler, J. F., Gupta, A., Solikhin, A., and Procter, J. N.: Erosion and aggradation on persistenly active volcanoes a case study from Semeru Volcano, Indonesia, Bull. Volcanol., 857, 26 pp., doi:10.1007/s00445-014-0857-z, 2014.

Vallance, J. W.: Lahars, in: Encyclopedia of volcanoes, edited by: Sigurdsson, H., Houghton, B., McNutt, S. R., Rymer, H., and Stix, J., Academic Press, New York, 601-616, 2000.

Vázquez, R., Capra, L., Caballero, L., Arámbula-Mendoza, R., and Reyes-Dávila, G.: The anatomy of a lahar: Deciphering the 15th September 2012 lahar at Volcán de Colima, Mexico, J. Volcanol. Geotherm. Res., 272, 126-136, 2014.

Vázquez, R., Suriñach, E., Capra, L., Arámbula-Mendoza, R., and Reyes-Dávila, G.: Seismic characterisation of lahars at Volcán de Colima, Mexico, Bull. Volcanol., 78, 14 pp. doi:10.1007/s00445-016-1004-9, 2016.

Walling, D. E. and Webb, B. W.: Erosion and sediment yield: a global overview, in: Proceedings of the Exeter Symposium, IAHS Publication, 236, 3-19, 1996. 